\title{
Factors Influencing Attitudes Towards the Use of CRM's Analytical Tools in Organizations
}

\author{
Urban Šebjan, Samo Bobek, Polona Tominc \\ Faculty of Economics and Business, University of Maribor, Razlagova 14, 2000 Maribor, Slovenia \\ urban.sebjan@um.si, samo.bobek@um.si, polona.tominc@um.si
}

Background and Purpose: Information solutions for analytical customer relationship management CRM (aCRM IS) that include the use of analytical tools are becoming increasingly important, due organizations' need for knowledge of their customers and the ability to manage big data. The objective of the research is, therefore, to determine how the organizations' orientations (process, innovation, and technology) as critical organizational factors affect the attitude towards the use of the analytical tools of aCRM IS.

Design/Methodology/Approach: To measure the orientation of the organization (process, innovation, and technology), we redesigned the existing scale, which was validated using exploratory factor analysis. In the next phase, we created a model by which we examined the impact of the organization's stance in relation to the use of the analytical tools of aCRM IS, where we used multiple regression analysis. The model was verified on a sample of Slovenian Organizations $(n=105)$, which use the analytical tools of aCRM IS for analyzing the data they have on their customers and business partners.

Results: In the study we found that all critical factors of the organization, specifically process, technology, and innovation orientation, have a positive impact on the attitudes towards using the analytical tools of aCRM IS. Innovation orientation is particularly important and has the strongest influence on the attitude towards using the analytical tools of aCRM IS. We found that innovation orientation on new ideas, methods, and approaches has the strongest effect, followed by the impact of innovation orientation on acceptance of novelty.

Conclusion: The more innovation-, technology-, and process-oriented organizations are, the more positive their attitude towards using the analytical tools of aCRM IS. The study is particularly important for organizations that are introducing an aCRM IS into their business system.

Keywords: critical organizational factors, analytical customer relationship management (aCRM), analytical tools, attitudes towards use of aCRM

\section{Introduction}

Organizations nowadays are forced into the use of different information solutions (IS) to deal with severe market competition, which leads to changes in customers' loyalty (Almotairi, 2009), as well as technical development in global networks, convergence, and interactivity (Peppard,
2000). The main phenomena leading to these circumstances are globalization, internationalization, deregulation, the progress of information technology, shorter products' lifecycles, and development of awareness of the connection between client retention and profitability (Chandra and Kumar, 2000; Zineldin and Jonsson, 2000; Sahay, 2003; Stefanou et al., 2003).

Received: $16^{\text {th }}$ October, 2015; revised: $26^{\text {th }}$ November 2015; accepted; $21^{\text {th }}$ December 2015 
However, it is not unusual that even enhanced efforts in organizations to use differentiated IS often do not bring satisfactory results. Literature review reveals several reasons, such as complexity regarding technical and organizational issues (Goodhue et al., 2002), organizational change, policy organizations, poor understanding of information solutions and poor skills using those solutions (Almotairi, 2009), lack of focus on human/social factors (King and Burgess, 2008; McCalla et al., 2003), thinking that technology becomes the solution, the lack of management support, lack of vision and strategy, poor quality of data and consequently of information, inadequate change management, development of IS that do not include the end user (Finnegan and Currie, 2010), etc.

Organizations are constantly trying to discover how to obtain the highest quality of information about their customers, which can help them make key business decisions as well as establish long-term and profitable relationships with customers, indirectly boosting the chances of business success (Gneiser, 2010). As a result, many organizations have decided to implement Customer Relationship Management as an information solution (CRM IS) and have very positive attitudes towards use of analytical solutions and possibilities that CRM IS enables (Rigby and Bilodeau, 2013). In 2013, CRM IS was the first most commonly used management tool worldwide (Rigby and Bilodeau, 2013). A survey in 2010 showed that in Slovenia, CRM IS was not the most commonly used tool by management, however, and it was used only as the seventh most frequently used tool (Potočan et al., 2012). With the development of technology, new forms of CRM IS (e.g., e-CRM, m-CRM, $\mathrm{s}$-CRM) have been developed that facilitate the collection of customer data with the widest possible perspective, with the creation of large-scale data warehousing and data mining as an important infrastructure of analytical customer relationship management as an information solution (aCRM IS) (Srivastava et al., 2002). When looking at the actual context of the economy, the analytical functions within the CRM IS (aCRM IS) become more important. A database with customers and the analytical functions overlaying that database could make the difference between a winner and a loser in the economic game (Furtuna and Barbulescu, 2012). It is expected that aCRM IS, which can discover knowledge from huge amounts of data, plays a crucial role in decision support (Xie et al., 2008).

Our research addresses the following key research question: How do the organizational factors within organizations affect the attitude towards using the aCRM IS? With the purpose to answer this key research question, the three main objectives of this research are: (i) identification of critical organizational factors, (ii) reliability and validity analysis of the measurement scales that were developed and used to measure different aspects of organizational orientation, and (iii) formation of a regression model of critical organizational factors affecting the attitudes towards using the aCRM IS within organizations.

\section{Literature review and hypothesis}

\subsection{Analytical tools of aCRM IS}

There are not many research results available regarding the in-depth use of an aCRM IS and the use of tools, techniques, and quantitative methods of an aCRM IS. On the other hand, the existing researches about the aCRM IS focus mainly on managing knowledge, on-line analytical mining, web mining, technologies, applications needed to implement aCRM IS (Ranjan and Bhatnagar, 2011; Feng et al., 2005; Tuzhilin, 2012; Srivastava et al., 2002; Chen et al., 2012), business intelligence, and data mining techniques of CRM solutions (Ngai et al., 2009; Zeng et al., 2012; Olson, 2006; D'Haena et al., 2013; Ranjan and Bhatnagar, 2010; Huang et al., 2012, 2013). They have also explore more general views of aCRM IS (Ranjan et al., 2011) rather than focusing on exploration of the application and usefulness of tools, techniques, and quantitative methods in aCRM IS in an organization. Therefore, this field remains a deficient area of research.

The researchers have so far investigated critical factors of use of CRM IS on the individual level, but not the organizational level. Through literature review, we have detected a heterogeneous terminology, which is reflected in the interpretation of quantitative methods and techniques of data mining. Only in recent years the most commonly used terminology refers to aCRM as the quantitative research methods used to process and analyze data and the use of software support for data mining (Zhang and Segall, 2010; Nonyelum Ogwueleka et al., 2012). Therefore, aCRM IS refers to the obtaining, storage, retrieval, integration, processing, interpretation, transmission, use, and reporting of the data related to customers in order to maximize the value of the data, not only for the customer but also for the organization (Buttle, 2009). It allows the organization to create in-depth summaries of the customer's purchase history, their preferences, and profitable information from the data warehouse and other organizations' databases. At the same time, aCRM IS facilitates analysis, forecasting, customer value creation, customer purchase behavior analysis, and also demand forecasting (O'Brien and Marakas, 2011). Additionally, aCRM IS creates statistical models of customers' behavior and the value of the relationship with customers through time, as well as forecasting the gain, retaining, and loss of customers (Rainer and Cegielski, 2012).

With the help of acquired customer data from the data warehouse organizations, the organization can create indepth analyses, whereby they can use a number of quantitative methods or so-called techniques of data mining, from simple to more sophisticated ones, such as student's t-test, Chi-square, analysis of variance (ANOVA), Mann-Whitney $\mathrm{U}$, regression analysis, correlation, Fisher's least significant difference test (such as Pearson product-moment correlation coefficient and Spearman's rank correlation coefficient), 
time series, cluster analysis, and neural network (Baran et al., 2008; Turban and Volonino, 2010; Kroenke, 2011).

\subsection{Organizational factors and attitudes towards the use of aCRM IS within organizations}

To date, researchers have particularly studied the organizational factors of successful application of a CRM IS in general (Kavosh et al., 2012; Bavarsad and Hosseinipour, 2013; Sarmaniotis et al., 2013), but they were less focused on factors that affect the application of the analytical tools of the aCRM IS. Reicher and Szeghegyi (2015) explored the factors affecting implementation of a CRM system in organizations. They defined three important factors of implementing a CRM system as strategic, technology, and human factors. Researchers have not studied the orientation of the organization in the field of application of analytical tools of the aCRM IS, and therefore findings in this area represent a significant scientific contribution.

Iriana and Buttle (2006) created a survey instrument to assess an organization's CRM IS orientation in terms of strategic, operational, and analytical perspectives. In development of a survey instrument, they have focused on CRM IS as a whole, but in the strategic CRM the innovative process and technological aspects were not included. These aspects are very important. Namely, important processes exist within and between the individual levels of CRM IS (collaborative, analytical, and operational CRM); An aCRM IS includes collecting and analyzing customers' information (Tufféry, 2011), which is why organizations require appropriate innovative analytical tools that are technologically supported and implemented into other processes within the organization. Analytical CRM also supports internalization processes, to some extent. For instance, employees can gain knowledge about customers by reading reports and analyses prepared using analytical systems (Khodakarami and Chan, 2014). According to Nazari-Shirkouhi et al. (2015), analytical CRM is able to determine customers' needs and predict their future needs along the path to the development of new products and services.

CRM is defined as a core business strategy wherein inside CRM organizations use a number of applications that present CRM solutions (Rajola, 2013, pp. 29; Buttle and Maklan, 2015). CRM solutions usually include a relational database for storing persistent information and software applications for handling business logic, and essentially becomes a database that contains key information about current and prospective customers (Peri and Pakroo, 2014, p. 220; Vaman, 2007, p. 47). These reasons may be reflected in the process orientation as well as in the technological and innovative stance of organizations. All three organizational orientations are the strategic components of the organization (Gatignon and Xuereb, 1997).

\section{The innovative orientation}

»An organization's ability to create, store and transfer knowledge about technologies, customer needs, and the innovation process itself may well determine success in bringing new products or services to the market« (Lee and Chang, 2007, pp. 145). This is also an important reason why organizations need information about customer needs, market changes, and competitor actions, as well as development of new technologies, more specifcally to create new products that are superior to those of competitors. Many successful organizations have developed customer information files from data that are routinely collected in an organization's various production systems to improve their segmentation and targeting efforts (Slater and Narver, 1998). From the organization's point of view, the aCRM IS offers the prospect of more powerful cross-selling and up-selling programs, and more effective customer retention and customer acquisition programs (Buttle and Maklan, 2015). Therefore, organizations need innovative approaches in the use of analytical tools. Organizations with a strong innovation orientation are more likely to implement policies, procedures, practices, and incentives specifically devoted to gathering and disseminating information about customer and competitor markets to stimulate and sustain innovation (Siguaw et al., 2006). Researchers found that having innovative management and an innovation culture in the organization has a significant impact on the perception of the use of CRM IS, technology of CRM IS, and the probability of accepting a CRM IS in organizations (Hung et al., 2010; Nguyen and Waring, 2013; Newby et al., 2014). The findings on CRM systems applications are reported, and an innovative aCRM system is proposed for customer knowledge acquisition (Xu and Walton, 2005). Nguyen and Waring (2013) found that the innovative management of an organization has significant influence and they recognized that innovation orientation has a positive impact on the adoption of CRM IS. Until now, researchers have found that innovation at an individual level has an impact on the perceived usefulness of CRM IS (Avlonitis et al., 2005). Therefore, it is important to study the innovative orientation of the organization.

Literature review supports the relevance of this research's objectives; namely, that development of measurement scales for organizations' technology, process, and innovation orientations affects the use of analytical tools of the aCRM IS, which would be sufficiently reliable and of sufficient quality for further use and research. Based on theoretical principles, the following hypothesis is offered:

H1: The higher the innovation orientation of organizations, the more positive in general the attitudes to use an aCRM IS within organizations will be.

\section{The process orientation}

Researchers involved in the study of the performance of different IS within organizations emphasize the role of business processes (Sternad Zabukovšek et al., 2007; 
Žabjek et al., 2009). Sternad Zabukovšek and coauthors (2011) also found that there is a positive correlation between organizational process characteristics of IS and the perceived usefulness of it. CRM IS focuses on the automation and improvement of processes within organizations (Xin et al., 2002). Business processes determine the nature of the entity's ability and its key competences for CRM IS (Liu, 2012). Efficient use of aCRM IS therefore depends on how the aCRM IS is integrated with existing processes and structures (Boulding et al., 2005). Chen and Popovich (2003) argue that CRM IS is the integrated approach, taking into account, inter alia, the process, so it is important that if the organization wants to use an aCRM IS, they should be process-oriented. This is particularly true in the implementation phase of CRM IS, because the transition from a vertically oriented organization to a process-oriented organization is an exceptionally complex and demanding process (Gentle, 2008). The researchers note that the lack of business process orientation leads to considerable delay in the process of implementing CRM IS (Raman et al., 2006; Owolabi et al., 2013). Therefore, we have designed the following hypothesis:

$\mathrm{H} 2$ : The higher the process orientation of organizations, the more positive in general the attitudes to use an aCRM IS within organizations will be.

\section{The technological orientation}

Technology oriented organizations encourage research and development activities, acquisition of new technology solutions, and using the latest technologies, and thereby they accumulate rich technology knowledge with the help of past experiences and processes, such as investment in research and development and the rapid acquisition of new technologies (Gatignon and Xuereb, 1997; Zheng Zhou and $\mathrm{Li}, 2010)$. Technological orientation should be seen as an incentive for the realization of CRM IS (Ryals and Knox, 2001; Bose, 2002). CRM IS requires the use of information technologies (IT) to capture, store, modify, and distribute large amounts of data to interested groups (Piccoli et al., 2003). Organizations that are planning to adopt the aCRM IS must be customer orientated, and attention must be paid to the data aspect of aCRM IS, its initial costs, and if significant change in the organization's processes is needed. Technology that enables data mining and data warehousing requires sufficient organizational buy in because the parts of the organization that will benefit the most from an aCRM IS are the business units, i.e., marketing, sales, etc., rather than the IT department (Cheng et al., 2002). With aCRM technologies, data stored in organizational databases are analyzed to help identify customer behavioral patterns, determine satisfaction levels, support customer segmentation, etc. (Xu and Walton, 2005). Chen and Popovich (2003) also designate the technology as an important factor of CRM IS and several studies show the positive relationship between the perceived usefulness of the new information solutions and attitude towards technology (Vijayasarathy, 2004; Plewa et al., 2012). Within aCRM IS the technology is used to accumulate, store, organize, interpret, distribute, and exploit customer data (Iriana and Buttle, 2006), which is also reflected in the technological orientation of the organization. Based on the presented theoretical basis, we designed a third and final hypothesis:

H3: The higher the technology orientation of organizations, the more positive in general the attitudes to use an aCRM IS within organizations will be.

\subsection{Attitudes towards the use of aCRM IS within organizations}

Empirical studies in different contexts and fields establish a connection between the perceived possibility of increased job performance with the use of IS and a positive attitude towards the use of IS technology within organization (Vijayasarathy, 2004; Chen et al., 2009; Plewa et al., 2012). Davis (1989) notes that it can be expected that the user who perceives an increased work performance using IS and IS applications without much effort has a positive attitude towards the use of IS. Employees in organizations therefore have different attitudes and beliefs about the use of IS (Chris and Chang, 2011), which are certainly linked to the characteristics of the previously described process, technological, and innovative orientation of their organizations. Also, Robinson and others (2005) have found that employees are more likely to use the offered CRM IS in an organization if they have a positive attitude towards the CRM IS. If employees believe that by using CRM IS the work will be performed efficiently (i.e., fast access and retrieval of information, targeting, etc.), then they will have a positive attitude towards the use of CRM IS (Beth et al., 2008).

Attitudes towards the use of IS in the organization is a component within the well-known Technology Acceptance Model (TAM), which covers the areas of perceived use, attitudes towards the use, and future intention to use the IS in a wide range of IS users (Davis, 1989, 1993). However, comprehensive treatment of TAM exceeds objectives set for the present research. Nevertheless, it certainly represents a possibility for future research, which we also discuss at the conclusion chapter of this paper.

\section{Methodology}

This research utilizes the quantitative research approach. It was conducted in the following stages. In the first phase, we reviewed the relevant scientific literature and resources. In the next phase, the survey questionnaire was developed. With the help of the questionnaire, we measured organizational factors of an aCRM IS, where we derived which orientations were of strategic importance to the organiza- 
tion, such as innovation, technology, and process orientation. In designing the measuring scales we considered the already established scales, which measure the innovation, technology, and process orientation of organizations, and we changed them respecting the use of analytical tools. For this process, we started from the already developed measuring scales: process orientation (Chen et al., 2009; Tang et al., 2013) and innovative orientation (Zheng Zhou et al., 2005a; Narver et al., 2004; Theodosiou et al., 2012) were measured with nine statements, and technological orientation (Gatignon and Xuereb, 1997; Zheng Zhou and Li, 2010; Zheng Zhou et al., 2005b; Kim et al., 2013) was measured with six statements. Agreement with the statements was assessed using the Likert scale ( 1 - completely disagree to 7 - completely agree). In the next phase, we submitted the e-questionnaire to the three organizations that will review the questionnaire to avoid any ambiguity in understanding and completing the questionnaire. For transformation of the scale orientation of the organization, we re-examined their measurement reliability, which represents our scientific contribution. The structure of the measurement scale is presented in Table 1.

In the next phase, we formed a model based on the literature review. The model was used to examine the effect of the organization's orientation on the attitude towards the use of analytical tools of the aCRM IS. So far researchers have not studied how the organization's orientation influences the attitude towards the use of analytical tools of an aCRM IS; therefore, our research makes an important contribution to the clarification of the use of analytical tools of an aCRM IS. The research model is presented in Figure 1.

Attitudes towards the use of aCRM IS were measured with a single item scale from 1 - strongly disagree to 7 strongly agree with the statement, »We have positive attitudes towards the use of analytical tools of an aCRM IS."

\subsection{Data collection}

A random sample of $n=833$ organizations was collected using the e-questionnaire (with two reminders), during the period from December 4, 2014 until March 27, 2015. The e-questionnaire was distributed using the web addresses of organizations with the help of the Slovenian Chamber of Commerce and companies who are dealing with the development of information technology business solutions. The mentioned organizations helped us in transmitting e-questionnaires to companies. The e-questionnaire was completed by managers or by persons who are responsible for CRM IS and analysis of customer data, suppliers, and business partners. Besides respondents, 18 organizations returned the questionnaire without participating in the survey. Specifically, they didn't want to participate because they believed that their use of comprehensive analytic tools for analyzing business areas was not at a sufficient level. The response to the survey was $12.6 \%$, which means that the final sample of $n=105$ organizations was formed. The structure of the sample of $n=105$ organizations is as follows:

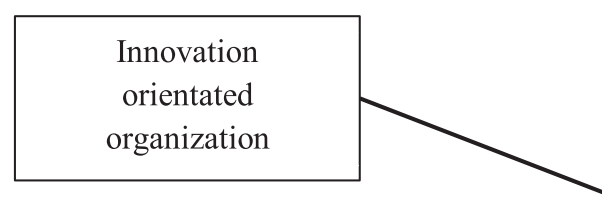

H1

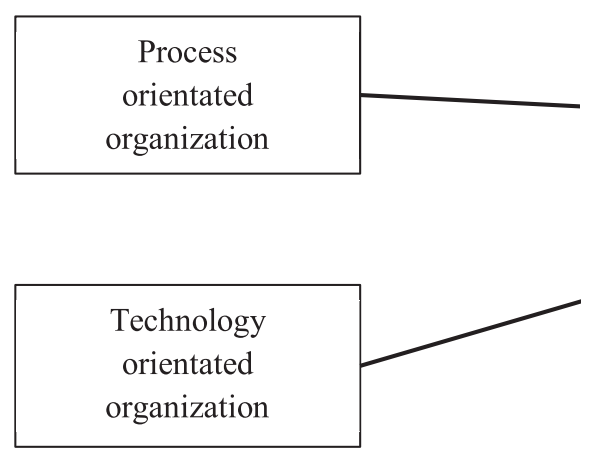

$\mathrm{H} 2$

H3

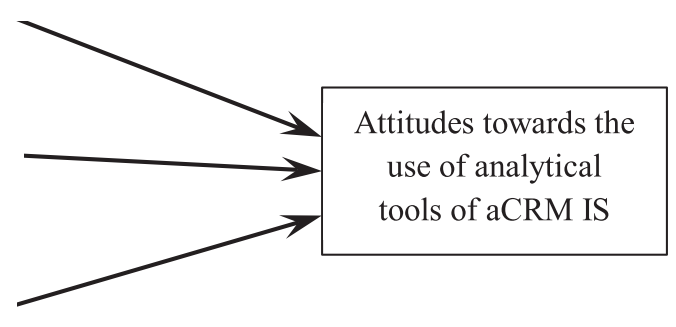

Figure 1: Research model.

(Source: Authors) 
Table 1: Measurement scale - process, technology, and innovation orientation of organizations.

\section{Different aspects of organizational orientation (process, technological and innovative):}

Q1. Usage of the tools for processing and analyzing of data about customers and business partners is a set of related processes.

Q2. When using tools for processing and analyzing of data about customers and business partners we are using the concepts of process (inputs, outputs, processes and process owners) in peer conversations.

Q3. Processes in the use of tools for processing and analyzing of data about customers and business partners have defined and documented using inputs and outputs to and from our customers / business partners.

Q4. Business processes in the application of tools for processing and analyzing of data about customers and business partners are sufficiently defined so people know what their jobs are.

Q5. The tasks using the tools for processing and analyzing of data about customers and business partners are usually multidimensional and not just simple tasks.

Q6. In the process of using tools for processing and analyzing of data about customers and business partners we are constantly learning new things.

Q7. The process for using the devices for processing and analyzing of data about customers and business partners (quality analysis, preparation time and analysis, cost analysis, preparation ...) is defined.

Q8. The objectives of the performance of devices for processing and analyzing of data about customers and business partners (target quality analysis, target cost, target time, target variability) are set.

Q9. The results of the application of tools for processing and analyzing of data about customers and business partners (real quality of analysis, the real target cost, real time, real variability) were measured.

Q10. In general, we believe that our employees in the use of tools for processing and analyzing of data about customers and business partners are creative and inclined to news.

Q11. We are trying to look for new methods, findings and innovative approaches in the use of tools for processing and analyzing of data about customers and business partners.

Q12. When using tools for processing and analyzing of data about customers and business partners we are trying to generate ideas and proposals for the effective and efficient implementation of analytical activities.

Q13. The organization we are trying to ensure that adequate resources (human, financial, organizational ...) to improve activities in the use of tools for processing and analyzing of data about customers and business partners.

Q14. In the organization we ensure an adequate plan for the development of new ideas and innovations in the use of tools for processing and analyzing of data about customers and business partners.

Q15. Much attention was paid to improving the use of tools for processing and analyzing of data about customers and business partners. Q16. Advances in the use of tools for processing and analyzing of data about customers and business partners are readily accepted in our organization.

Q17. In organization we see the need to encourage the development and exploitation of resources in the use of tools for processing and analyzing of data about customers and business partners.

Q18. The organization's management encourages employees to suggest ideas for improving the efficiency of the use of tools for processing and analyzing of data about customers and business partners.

Q19. We are quick in inclusion of new technology to use tools for processing and analyzing of data about customers and business partners. Q20. In organization we strive to connect with each other the various technologies that support the devices to process and analyze data about customers and business partners.

Q21. To a large extent we use technology that allow us to use tools to perform complex analyzes under cultivation and analysis of information about clients and business partners.

Q22. Our organization is very active in developing new technologies that support utilities for manipulating and analyzing data about customers and business partners.

Q23. Compared with the competition, we have more technical knowledge that supports devices to process and analyze data about customers and business partners.

Q24. Our aim is to develop technology that would respond to the changing needs of devices for processing and analyzing the information about clients and business partners.

(Source: Authors) 
- The majority of companies were large organizations with more than 250 employees (59.0\%), followed by medium-sized organizations $(26.7 \%)$, small organizations $(10.5 \%)$, and micro organizations $(3.8 \%)$. The size breakdown of participating organizations was expected, as large organizations in general have the most advanced customer relationship management, have extensive databases of customers, and apply statistical and analytical software for analyzing complex databases (Phillips-Wren and Hoskisson, 2015).

- Almost two thirds of the companies in the sample were from the service sector $(62.9 \%)$, while $37.1 \%$ of organizations were from the manufacturing sector. The majority of respondent organizations were engaged in commercial activity and sales; followed by financial institutions (banks and insurance companies); manufacturing organizations, which are engaged with energy and logistics; information technology organizations; pharmacy organizations; and food processing organizations.

- More than half of the observed organizations have made a significant proportion of revenue in international markets $(54.3 \%)$, while $45.7 \%$ of organizations have made a significant proportion of their revenue in the domestic market, namely in Slovenia.

- Regarding the analytical tools that organizations use in the context of relations with customers and business partners, $49.5 \%$ of organizations most frequently analyze and manage relations with individuals or end customers, while $50.5 \%$ of the organizations most often analyze and manage relations with other legal entities, such as business partners, suppliers, and other organizations.

Table 2: Results of EFA - factors of organizational orientation regarding processes, technology, and innovations.

\begin{tabular}{|c|c|c|c|c|c|c|c|c|c|c|}
\hline \multirow[t]{2}{*}{ Items } & \multirow[t]{2}{*}{ Communality } & \multicolumn{4}{|c|}{ Factors } & \multirow{2}{*}{$\begin{array}{c}\text { Cronbach } \\
\alpha\end{array}$} & \multirow[t]{2}{*}{ Mean } & \multirow[t]{2}{*}{$\mathbf{a}_{ \pm \mathrm{SD}}$} & \multicolumn{2}{|c|}{$\begin{array}{l}\text { 95\% Confidence } \\
\text { Interval for Mean }\end{array}$} \\
\hline & & 1 & 2 & 3 & 4 & & & & Lower & Upper \\
\hline Q18 & 0.798 & 0.844 & & & & \multirow{6}{*}{0.926} & 5.02 & 1.56 & 4.71 & 5.32 \\
\hline Q17 & 0.802 & 0.809 & & & & & 4.95 & 1.40 & 4.68 & 5.22 \\
\hline Q20 & 0.702 & 0.729 & & & & & 5.23 & 1.29 & 4.98 & 5.48 \\
\hline Q14 & 0.774 & 0.692 & & & & & 4.55 & 1.59 & 4.25 & 4.86 \\
\hline Q15 & 0.759 & 0.683 & & & & & 4.71 & 1.47 & 4.43 & 5.00 \\
\hline Q21 & 0.751 & 0.626 & & & & & 4.69 & 1.64 & 4.37 & 5.00 \\
\hline Q20 & 0.831 & & 0.889 & & & \multirow{3}{*}{0.841} & 5.62 & 1.16 & 5.40 & 5.84 \\
\hline Q21 & 0.733 & & 0.756 & & & & 5.60 & 1.11 & 5.39 & 5.81 \\
\hline Q10 & 0.779 & & 0.748 & & & & 5.20 & 1.40 & 4.93 & 5.47 \\
\hline Q8 & 0.796 & & & 0.759 & & \multirow{6}{*}{0.857} & 4.98 & 1.49 & 4.69 & 5.27 \\
\hline Q7 & 0.698 & & & 0.745 & & & 4.70 & 1.43 & 4.42 & 4.97 \\
\hline Q3 & 0.677 & & & 0.740 & & & 5.06 & 1.52 & 4.76 & 5.35 \\
\hline Q9 & 0.733 & & & 0.703 & & & 4.77 & 1.63 & 4.46 & 5.09 \\
\hline Q2 & 0.485 & & & 0.653 & & & 4.56 & 1.68 & 4.24 & 4.89 \\
\hline Q1 & 0.525 & & & 0.629 & & & 5.90 & 1.21 & 5.67 & 6.14 \\
\hline Q23 & 0.808 & & & & 0.857 & \multirow{3}{*}{0.875} & 4.62 & 1.46 & 4.34 & 4.90 \\
\hline Q24 & 0.745 & & & & 0.772 & & 4.76 & 1.57 & 4.46 & 5.06 \\
\hline Q22 & 0.817 & & & & 0.712 & & 4.11 & 1.72 & 3.78 & 4.45 \\
\hline
\end{tabular}

Bartlett test of sphericity $(\mathrm{BTS})=1362.950$; Kaiser-Meyer-Olkin statistics $(\mathrm{KMO})=0.886$; Statistically significant (Sig.) $p$ $<0.001$; Explain total variance $=73.43 \%$

Note: $a_{ \pm S D-\text { standard deviations. }}$

(Source: Authors) 


\subsection{Methodological tools}

For testing the research hypotheses, regression analysis was used. An f-test was used to test the regression model, while the statistical significances of regression coefficients were tested using the t-test (Janssens et al., 2008), at a 5\% significance level.

To establish the structure of influencing factors representing explanatory variables in the regression model, exploratory factor analysis (EFA) was used. Bartlett's Test of Sphericity (BTS) and Kaiser-Meyer-Olkin statistics (KMO) were calculated (Janssens et al., 2008). The independency of factors and a more simple factor structure were obtained using the principal component analysis (PCA) and the Varimax rotation. The criteria that factor loadings of each item and item-total correlation coefficients (CITC) for each item must exceed 0.5 were used to guarantee the reliability and validity of the questionnaire scale (Nunnally, 1978). EFA was also used to establish a scale dimensionality by checking the factorial structure of items (indicators).

\section{Results}

As already described, the questionnaire used included statements (items) about the three aspects of organizational orientation: process, technological, and innovative orientation, as well the assessment of attitudes towards the use of analytical tools of an aCRM IS.

With the purpose to test hypotheses $\mathrm{H} 1, \mathrm{H} 2$, and $\mathrm{H} 3$, we firstly present the results of the factor analysis. The results of the factor analysis indicate that it is meaningful to use EFA (KMO $>0.5$; BTS significance $\mathrm{p}<0.001)$ and the results lead to the four-dimensional factor solution. The varimax factor rotation led to the structure of factors as presented in Table 2. EFA shows that variables (items)
Q4, Q5, Q6, Q13, Q16, and Q19 have factor loadings lower than 0.5 ; therefore, they have been excluded from further analysis.

According to the factor loadings, factor 1 describes »Innovation orientation - technologies and tools, « while factor 2 describes »Innovation orientation - new ideas and approaches. « Factor 3 was named »Technological orientation« and factor 4 »Process orientation.« All four obtained measurement scales proved high reliability (Cronbach Alpha $>0.7$ ). A total $73.43 \%$ of total variance is explained by the four factors formed.

Regression analysis results are presented in Table 3. The value of the adjusted coefficient of determination indicates that $46.7 \%$ of the variation in the attitudes towards the use of an aCRM IS may be explained by the variation in the four independent variables (factors) included into the analysis. The model as a whole is significant $\left(\mathrm{F}_{4,100}=23.811, p\right.$ $<0.001$ ), the model is meaningful, and a good fit is present between the model and the data. The regression model with standardized coefficients is presented in Figure 2.

All four factors are significant - partial regression coefficients are all statistically significant $(p<0.01)$ and all have the expected sign; all regression coefficients are positive, as expected. The higher each component of organizational orientation is, the greater the positive attitudes towards the use of analytical tools of an aCRM IS. Therefore, all three hypotheses are confirmed.

\section{Discussion}

We tested the hypothesis that the process orientation, technological orientation, and innovation orientation of organizations have a positive impact on the attitudes towards the use of the analytical tools of an aCRM IS within organizations. All of these hypotheses were confirmed.

Table 3: Multiple regression analysis results (dependent variable: attitude towards the use of analytical tools of aCRM IS)

\begin{tabular}{|c|c|c|c|c|c|c|}
\hline \multirow{2}{*}{ Structural relationship } & \multirow{2}{*}{$\mathbf{B}^{\mathbf{a}}$} & \multirow{2}{*}{$\beta^{\mathbf{b}}$} & \multirow{2}{*}{ Std. error } & \multirow{2}{*}{ t-value } & \multicolumn{2}{|c|}{ 95\% Confidence Interval for B } \\
\hline & & & & & Lower & Upper \\
\hline 1. IO1 $\rightarrow$ AT & $0.398^{* * *}$ & 0.393 & 0.072 & 5.489 & 0.254 & 0.541 \\
\hline 2. $\mathrm{IO} 2 \rightarrow \mathrm{AT}$ & $0.464^{* * *}$ & 0.459 & 0.072 & 6.413 & 0.321 & 0.608 \\
\hline 3. $\mathrm{PO} \rightarrow \mathrm{AT}$ & $0.243^{* *}$ & 0.240 & 0.072 & 3.351 & 0.099 & 0.386 \\
\hline 4. $\mathrm{TO} \rightarrow \mathrm{AT}$ & $0.259^{* *}$ & 0.256 & 0.072 & 3.573 & 0.115 & 0.402 \\
\hline
\end{tabular}

Notes: ${ }^{a}$ Unstandardized coefficients, ${ }^{b}$ Standardized coefficients; AT-Attitudes towards the use analytical tools of an aCRM IS (dependent variable); IO1 - Innovation orientation - technology, tools; IO2 - Innovation orientation - new ideas, approaches; PO-process orientated organization, TO-technology orientated organization. ${ }^{* * *} p<0.001 ;{ }^{* *} p<0.01$.

(Source: Authors) 


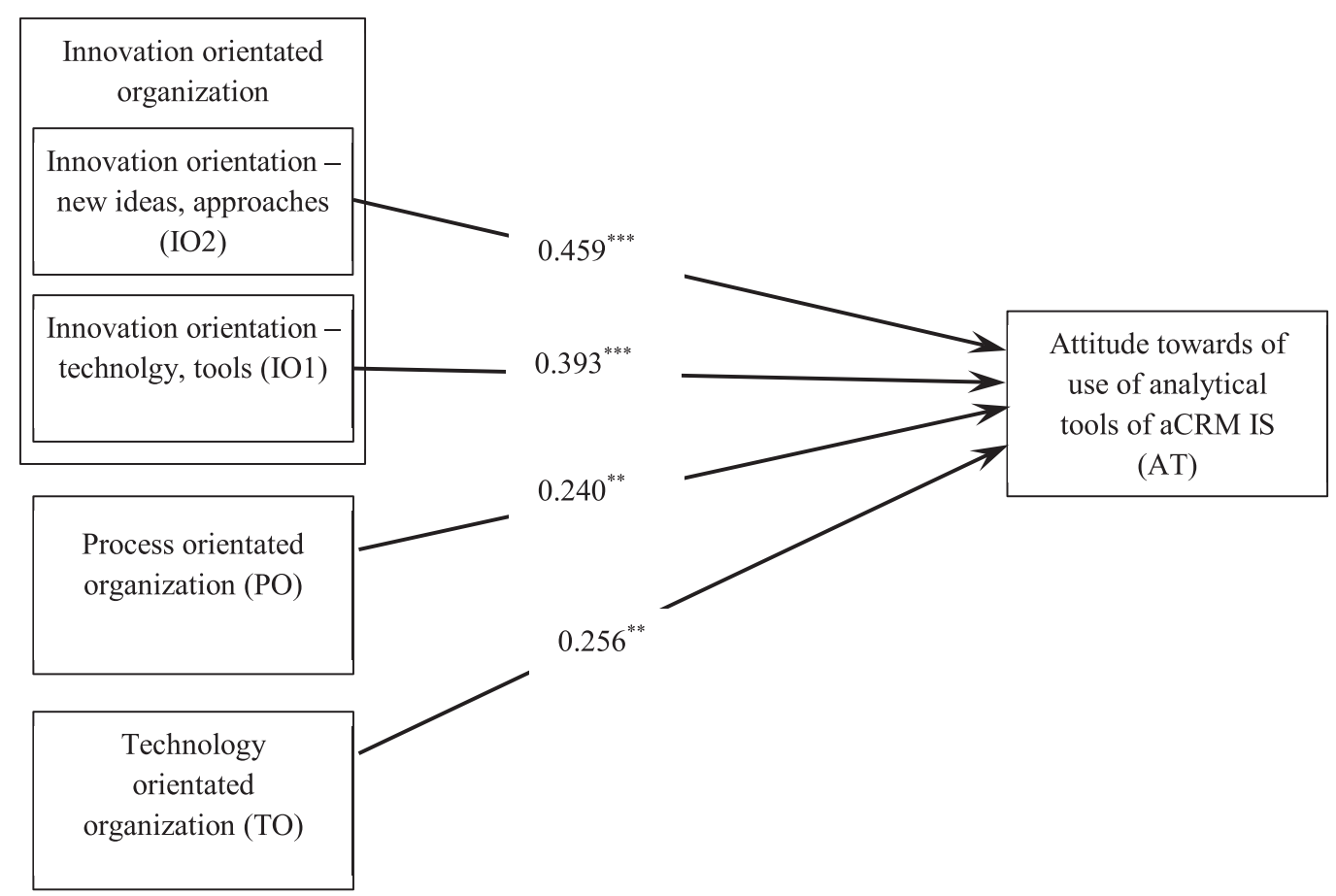

Figure 2: Regression model with standardized coefficients.

(Source: Authors)

One important result that we found is that innovation orientation has the highest positive impact on positive attitudes towards organizations' use of the analytical tools of an aCRM IS, which accounts for innovations regarding new technologies and tools, as well as new ideas and approaches. In our study, we found that even an innovative stance of the organizations is reflected in the perceived attitudes towards the use of the analytical tools of an aCRM IS. The analytical tools of aCRM IS should not be seen as a routine accessory (it is constantly adapting as technology evolves). However, the analytical tools of an aCRM IS, which offer organizations new insights into innovative approaches, are reflected in the market through new products and approaches to clients. In organizations, knowing how to meet customer needs is a constant question. In turn, this means finding new ways of mining data, which requires the use of analytical tools like an aCRM IS.

We also found that, as more organizations are process and technology oriented, there are more positive attitudes towards the use of the analytical tools of an aCRM IS. Such correlations were expected, as the analytical tools of an aCRM IS are incorporated in the process of work within each level of management. Furthermore, such analytical tools are incorporated all the way to the point where organizations face their customers, which is reflected through the collaboration of an aCRM IS. The analytical tools of an aCRM IS can be very useful for establishing customer relationships, which are then built upon. For an organization to be able to successfully pursue its relationship with its customers, it must clearly define the processes within the organization, as well as to its customers, which is part of process orientation. The second most important factor in our model is the technology orientation. These results are also expected, since technologically oriented organizations advocate research and development activities, the acquisition of new technological solutions and the use of the latest technologies. They accumulate rich technological knowledge through previous experience and processes, and quickly adopt new technologies (Zheng Zhou and Li, 2010). The results of our study are also supported by the findings in literature that state that the adoption of an aCRM IS in organizations depends on the technology that is used for data analyses (Ranjan and Bhatnagar, 2011). The analytical tools of an aCRM IS are already used with hardware and software support, which means that an organization must provide relevant technology and software support that support analytical tools and utilities. If an organization sufficiently invests in new technologies and software to manage customers, then wider support and positive attitude of employees in using the analytical tools of an aCRM IS can also be expected. 
Organizations' primary focus should be on investing in applied technology solutions and software support that will enable the effective use of analytical tools and utilities. Until now, researchers have not studied the attitudes of organizations towards the use of CRM IS as a whole nor the attitudes towards the use of the analytical tools of an aCRM IS. The primary focus of previous research was on the critical factors for organizations to use CRM IS as a whole, but not aCRM IS and the analytical tools of the aCRM IS.

In our study, we limited ourselves to three types of organization orientation: process, technological, and innovative attitude. This is because these factors in aCRM IS have not yet been studied. In designing the research model, we restricted ourselves to the attitude towards the use of the analytical tools of the aCRM IS, which derives from TAM. There are theoretical studies on the critical factors of the use of aCRM IS, but not many on the impact that they have. Researchers have commonly associated organizational factors with the contracts of TAM as perceived use and perceived ease of use, but not in relation to the use of technology and IT solutions. There are studies that mainly focus on the technologies and solutions at the level of individuals, but not at the level of the whole organization (Šumak et al., 2011; Son et al., 2012; Sternad Zabukovšek and Bobek, 2013). In our study, we restricted ourselves to the study of the attitudes and use of analytical tools on the individual level, which arise from TAM and the critical factors at the organization level. Our study is important for organizations that would like to implementet or introduce an aCRM IS in their business system. Through the scientific method, we proved how important the relationship is between the organizational factors and attitudes towards the use of analytical tools of an aCRM IS on the individual level.

There are also several possible extensions of our research that could enrich the discussion. As already mentioned, the attitudes towards the use of analytical tools of an aCRM IS within organizations may be represented as a multidimensional variable in the Technology Acceptance Model (TAM). In further research, we believe that it would be reasonable to extend TAM with the influential factors of organizational orientation, specifically with the multidimensional variables that we have formed in the present study. Since aCRM IS uses extensive databases of statistical data on customers, the increasing need for the knowledge of statistical tools and methods is expected (Raeside and Walker, 2001). We believe that when analysing the analytical tools of an aCRM IS, the knowledge and skills of the statistical tools should be considered and TAM should be expanded to also include this aspect.

\section{Conclusions}

The use of analytical tools of an aCRM IS is an extremely promising area for research, yet it has not been the focus of many studies. It is a particularly promising area for research because organizations are being increasingly faced with »big data, « the need for information about customers, market demands, and new products. In turn, these require the use of analytical tools of an aCRM IS. The use of new analytical instruments and tools of an aCRM IS also encourages the development of new technologies and software support. Our study has found that, in order to give an organization a positive attitude towards the use of the analytical tools of an aCRM IS, organizations must be innovative, process, and technology oriented. It is particularly important to be innovative oriented, as new ideas and approaches have the most significant impact on the attitude towards the use of the tools of aCRM IS. In relation to the use of analytical tools, aCRM IS also has an influence on the attitudes towards the use of new technologies and other tools. Out of the three orientations, innovative and technological orientation have the strongest impact. The use of the analytical tools of an aCRM IS requires the use of appropriate technology and software support, new ideas and approaches, and knowledge on how to use them to obtain new and interesting information about customers. This is important for strategic decision making in the management of organizations. In considering the organizations' stance, we must also take into account the orientation process, which has a significant impact on the attitude towards the use of the analytical tools of an aCRM IS. Analytical tools are an integral part of the customer management process and at the management level, depending on what kind of information is needed and what decisions are accepted. The use of analytical tools is not only helpful for strategic management support, but also throughout the organization in general. Thus, we researched the orientation of the organizations in relation to their use of the analytical tools of an aCRM IS.

\section{Literature}

Almotairi, M. (2009). A framework for successful CRM implementation. European and Mediterranean Conference on Information Systems, July 13-14, 1-14, http://dx.doi. org/10.1509/jmkg.2005.69.4.167.

Avlonitis, G., Nikolaos, J. \& Panagopoulos, G. (2005). Antecedents and consequences of CRM technology acceptance in the sales force. Industrial Marketing Management, 34(4), 355-368, http://dx.doi.org/10.1016/j.indmarman.2004.09.021

Baran, R. J., Galka, R. J. \& Strunk, D.P. (2008). Principles of Customer relationship management. Mason: Thomson/SouthWestern.

Bavarsad, B. \& Hosseinipour, G. (2013) Studying the Factors Affecting the Customer Relations Management (CRM) in Marun Petrochemical Company. Interdisciplinary Journal of Contemporary Research in Business, 4(11), 845-857.

Beth, R., Merlin, S. \& Bryan, F. (2008). Integrating the value of salespeople and systems: Adapting the benefits dependency network. Journal of Database Marketing \& Customer 
Strategy Management, 15(4), 221-232, http://dx.doi. org/10.1057/dbm.2008.19

Bose,R.(2002)Customerrelationshipmanagement:key components for IT success. Industrial Management \& Data Systems, 102 (1/2), 89-97, http://dx.doi.org/10.1108/02635570210419636

Boulding, W., Staelin, R., Ehret, M. \& Johnston, W. (2005). A customer relationship management roadmap: what is known, potential pitfalls, and where to go. Journal of Marketing, 69(4), 155-166, http://dx.doi.org/10.1509/jmkg.2005.69.4.155

Buttle, F. (2009). Customer relationship management. Concepts and technologies. Oxford: Butterworth-Heinemann, Elsevier.

Buttle, F. \& Maklan, S. (2015). Customer Relationship Management: Concepts and Technologies. Oxon: Routledge.

Chandra, C. \& Kumar, S. (2000). Supply chain management in theory and practice: a passing fad or a fundamental change? Industrial Management in Data Systems, 100(3), 100-114, http://dx.doi.org/10.1108/02635570010286168

Chen, H., Chiang, R. H. L. \& Storey, V. C. (2012). Business intelligence and analytics: from big data to big impact. MIS Quarterly, 36(4), 1165-1188. http://dx.doi.org/10.1145/ 2133806.2133826

Chen, I. J. \& Popovich, K. (2003). Understanding customer relationship management (CRM): People, process and technology. Business Process Management Journal, 9(5), 672-688, http://dx.doi.org/10.1108/14637150310496758

Chen, V. J., Yen, D. C. \& Chen, K. (2009). The acceptance and diffusion of the innovative smart phone use: A case study of a delivery service company in logistics. Information \& Management, 46(4), 241-248, http://dx.doi.org/10.1016/j. im.2009.03.001

Cheng, M. -S., Yu, P. S. \& Liu, B. (Eds) (2002). Advances in Knowledge Discovery and Data Mining: 6th Pacific-Asia Conference, PAKDD 2002, Taipei, Taiwan. Springer: New York.

Chris, J. -S. L. \& Chang, H. -C. (2011). The role of technology readiness in self-service technology acceptance. Managing Service Quality, 21(4), 424-444, http://dx.doi.org/ $10.1108 / 09604521111146289$

D’Haena, J., Van den Poela, D. \& Thorleuchterb, D. (2013). Predicting customer profitability during acquisition: Finding the optimal combination of data source and data mining technique. Expert Systems with Applications, 40(6), 2007-2012, http://dx.doi.org/10.1016/j.eswa.2012.10.023

Davis, F. D. (1989). Perceived Usefulness, Perceived Ease Of Use, And User Accep. MIS Quarterly, 13(3), 319-340, http:// dx.doi.org/10.2307/249008

Davis, F. D. (1993). User acceptance of information technology: system characteristics, user perceptions and behavioral impacts. International Journal of Man-Machine Studies, 38(3), 475-487, http://dx.doi.org/10.1006/imms.1993.1022

Feng, C., Cong, W. \& Jie, L. (2005). Agent-based on-line analyticalmining in CRM system. IEEE International Conference on Networking, Sensing and Control, March 19-22, 169-173.

Finnegan, F. D. \& Currie, W.L. (2010). A multi-layered approach to CRM implementation: An integration perspective. European Management Journal, 28, 153-167, http://dx.doi.org/ 10.1016/j.emj.2009.04.010

Furtuna, T. F. \& Barbulescu, A. (2012). The usage of datamining techniques in analytical CRM. International Conference on Informatics in Economy, May 10-11, 352-355.
Gatignon, H. \& Xuereb, J.M. (1997). Strategic orientation of the firm and new product performance. Journal of marketing research, 34(1), 77-90, http://dx.doi.org/10.2307/3152066

Gentle, M. (2008). The CRM Project management handbook. Building realistic expectations and managing risk. London: Kogan Page Limited.

Gneiser, M. S. (2010). Value-Based CRM. The Interaction of the Triad of Marketing, Financial Management, and IT. Business \& Information Systems Engineering, The International Journal of Wirtschaftsinformatik, 2, 95-103.

Goodhue, D. L., Wixom, B.H. \& Watson, H. J. (2002). Realizing business benefits through CRM: hitting the right target in the right way. MIS Quarterly Executive, 1(2), 79-94.

Huang, T. C. -K., Liu, C. -C. \& Chang, D. -C. (2012). An empirical investigation of factors influencing the adoption of data mining tools. International Journal of Information Management, 32, 257-270, http://dx.doi.org/10.1016/j.ijinfomgt.2011.11.006

Huang, T. C. -K., Wu, I. L. \& Chou, C. -C. (2013). Investigating use continuance of data mining tools. International Journal of Information Management, 33, 791-801, http://dx.doi. org/10.1016/j.ijinfomgt.2013.05.007

Hung, S. -Y., Hung, W. -H., Tsai, C. -A. \& Jiang, S. -C. (2010). Critical factors of hospital adoption on CRM system: Organizational and information system perspectives. Decision Support Systems, 48, 592-603, http://dx.doi.org/10.1016/j. dss.2009.11.009

Iriana, R. \& Buttle, F. (2006). Strategic, Operational, and Analytical Customer Relationship Management: Attributes and Measures. Journal of Relationship Marketing, 5(4), 23-42, http://dx.doi.org/10.1300/J366v05n04 03

Janssens, W., Wijnen, K., De Pelsmacker, P. \& Van Kenhove, P. (2008). Marketing Research with SPSS, Pearson Education: Harlow: Englans.

Khodakarami, F. \& Chan, Y. E. (2014). Exploring the role of customer relationship management (CRM) systems in customer knowledge creation. Information \& Management, 51, 27-42, http://dx.doi.org/10.1016/j.im.2013.09.001

Kavosh, K., Abu Bakar, A. H., Melati, A. A. \& Siti Zaleha, A. R. (2012) Critical success factors in customer relationship management implementation. International Journal of Management Sciences and Business Research, 1(6), 1-13.

Kim, N., Im, S. \& Slater, S.F. (2013). Impact of Knowledge Type and Strategic Orientation on New Product Creativity and Advantage in High-Technology Firms. Journal of Product Innovation Management, 30(1), 136-153, http://dx.doi.org/ 10.1111/j.1540-5885.2012.00992.x

King, S. F. \& Burgess, T. F. (2008). Understanding success and failure in customer relationship management. Industrial Marketing Management, 37, 421-431, http://dx.doi.org/ 10.1016/j.indmarman.2007.02.005

Kroenke, D. M. (2011). Using MIS. Boston: Pearson.

Kumar, V. \& Reinartz, W. (2012). Customer Relationship Management: Concept, Strategy, and Tools. Springer: New York.

Lee, M. C. \& Chang, T. (2007). Linking knowledge management and innovation management in e-business. International Journal of Innovation and Learning, 4(2), 145-159, http:// dx.doi.org/10.1504/IJIL.2007.011690

Liu, C. C., Tseng, H. C., Chuang, L.M. \& Huang, C. M. (2012). A Study of the Impact of the e-CRM Perspective on Customer Satisfaction and Customer Loyalty-Exemplified by Bank 
Sinopac. Journal of Economics and Behavioral Studies, 4(8), 467-476.

McCalla, R., Ezingeard, J. -N. \& Money, K. (2003). A Behavioural Approach to CRM Systems Evaluation. Electronic Journal of Information Systems Evaluation, 6(2), 145-154.

Narver, J. C., Slater, S. F. \& Maclachlan, D. L. (2004). Responsive and proactive market orientation and new-product success. Journal of Product Innovation Management, 21(5), 334-347, http://dx.doi.org/10.1111/j.0737-6782.2004.00086.x

Nazari-Shirkouhi, S., Keramati, A. \& Rezaie, K. (2015). Investigating the effects of customer relationship management and supplier relationship management on new product development.

Tehnički vjesnik, 22(1), 191-200, http://dx.doi.org/10.17559/ TV-20140623130536

Newby, M., Nguyen, T.H. \& Waring, T.S. (2014). Understanding customer relationship management technology adoption in small and medium-sized enterprises An empirical study in the USA. Journal of Enterprise Information Management, 27(5), 541-560, http://dx.doi.org/10.1108/JEIM-11-2012-0078

Ngai, E. W. T, Xiu, L. \& Chau, D. C. K. (2009). Application of data mining techniques in customer relationship management: A literature review and classification. Expert Systems with Applications, 36, 2592-2602, http://dx.doi.org/10.1016/j. eswa.2008.02.021

Nonyelum Ogwueleka, F., Misra, S, Colomo-Palacios, R \& Fernandez, L. (2012). Neural network and classification approach in identifying customer behavior in the banking sector: A case study of an international bank. Human factors and ergonomics in manufacturing \& service industries, 25(1), 1-15, HTTP://DX.DOI.ORG/10.1002/HFM.20398

Nguyen, T. U. H. \& Waring, T. S. (2013). The adoption of customer relationship management (CRM) technology in SMEs. Journal of Small Business and Enterprise Development, 20(4), 824-848, http://dx.doi.org/10.1108/JSBED-01-20120013

Nunnally, J. C. (1978): Psychometric Theory. Mc-Graw-Hill Book Company: New York.

O‘Brien, J. A. \& Marakas, G. M. (2011). Management Information System. New York: McGraw-Hill Companies.

Olson, D. L. (2006). Data mining in business services. Service Business, 1(3), 181-193, http://dx.doi.org/10.1007/s11628006-0014-7

Owolabi, O. O., Adeleke, O. Y. \& Abubakar, K. (2013). Technology Enabled Customer Relationship Management in Supermarket Industry in Nigeria. American Journal of Industrial and Business Management, 3, 222-228, http://dx.doi.org/10.4236/ ajibm.2013.32027

Peppard, J. (2000). Customer Relationship Management (CRM) in Financial Services. European Management Journal, 18(3), 312-327, http://dx.doi.org/10.1016/S0263-2373(00)00013-X

Peri, H. \& Pakroo, J. D. (2014). The Small Business Start-Up Kit for California. Nolo: California.

Phillips-Wren, G. \& Hoskisson, A. (2015). An analytical journey towards big data. Journal of Decision Systems, 24(1), 87-102, http://dx.doi.org/10.1080/12460125.2015.994333

Piccoli, G., O'connor, P., Capaccioli, C. \& Alvarez, R. (2003). Customer relationship management - a driver for change in the structure of the US lodging industry. Cornell Hotel and Restaurant Administration Quarterly, 44(4), 61-73, http:// dx.doi.org/10.1016/S0010-8804(03)90259-X
Plewa, C., Troshani, I., Francis, A. \& Rampersad, G. (2012). Technology adoption and performance impact in innovation domains. Industrial Management \& Data Systems, 112(5), 748-765, http://dx.doi.org/10.1108/02635571211232316

Potočan, V., Nedelko, Z. \& Mulej, M. (2012). Influence of Organizational Factors on Management Tools Usage in Slovenian Organizations. Inzinerine Ekonomika-Engineering Economics, 23(3), 291-300, http://dx.doi.org/10.5755/j01. ee.23.3.1933

Rainer, R. K. \& Cegielski, C.G. (2012). Introduction to Information Systems Supporting and Transforrning Business. New York: John Wiley \& Sons.

Raeside, R. \& Walker, J. (2001). Knowledge: The key to organisational survival. The TQM Magazine, 13(3), 156-160, http:// dx.doi.org/10.1108/09544780110366105

Rajola, F. (2013). Customer Relationship Management: Organizational and Technological Perspectives. Milan: Springer.

Raman, P., Wittmann, C., \& Rauseo, N. (2006). Leveraging CRM for sales: the role of organizational capabilities in successful CRM implementation. Journal of Personal Selling and Sales Management, 26(1), 39-53, http://dx.doi.org/10.2753/ PSS0885-3134260104

Ranjan, J. \& Bhatnagar, V. (2010). Application of data mining techniques in the financial sector for profitable customer relationship management. International Journal of Information and Communication Technology, 2(4), 342-354, http://dx.doi. org/10.1504/IJICT.2010.034976

Ranjan, J. \& Bhatnagar, V. (2011). Role of knowledge management and analytical CRM in business: datamining based framework. The Learning Organization, 18(2), 131-148, http:// dx.doi.org/10.1108/09696471111103731

Ranjan, J., Singh, R. \& Bhatnagar, V. (2011). Analytical customer relationship management in insurance industry using data mining: a case study of Indian insurance company. Journal International Journal of Networking and Virtual Organisations, 9(4), 331-366, http://dx.doi.org/10.1504/ IJNVO.2011.043803

Reicher, R. \& Szeghegyi, A. (2015). Factors Affecting the Selection and Implementation of a Customer Relationship Management (CRM) Process. Acta Polytechnica Hungarica 12 (4): 183-200.

Rigby, D. \& Bilodeau, B. (2013). Management tools \& trends 2013. Retrived October 13, 2015, from http:/www.bain. com/Images/BAIN_BRIEF_Management_Tools_\%26_ Trends_2013.pdf

Robinson, L., Marshall, G. \& Stamps, M. (2005). Sales force use of technology: Antecedents to technology acceptance. Journal of Business Research, 58(12), 1623-1631, http://dx.doi.org/ 10.1016/j.jbusres.2004.07.010

Ryals, L. \& Knox, S. (2001). Cross-functional issues in the implementation of relationship marketing through customer relationship management. European Management Journal, 19(5), 534-542, http://dx.doi.org/10.1016/S0263-2373(01)00067-6

Sahay, B. S. (2003). Understanding trust in supply chain relationships. Industrial Management in Data Systems, 103(8), 553-563, http://dx.doi.org/10.1108/02635570310497602

Sarmaniotis, R., Assimakopoulos, C. \& Papaioannou, P. (2013). Successful implementation of CRM in luxury hotels: determinants and measurements. EuroMed Journal of Business, 8(2), 134-153, http://dx.doi.org/10.1108/EMJB-06-2013-0031 
Siguaw, J. A., Simpson, P. M. \& Enz, C.A. (2006). Conceptualizing Innovation Orientation: A Framework for Study and Integration of Innovation Research. The journal of product innovation management, 23, 556-574, http://dx.doi. org/10.1111/j.1540-5885.2006.00224.x

Slater, S. F. \& Narver, J. C. (1998). Customer-led and market-oriented: let's not confuse the two. Strategic Management Journal, 19, 1001-1006, http://dx.doi.org/10.1002/(SICI)1097-0266 (199810)19:10<1001::AID-SMJ996>3.0.CO;2-4

Son, H., Park, Y. Kim, C. \& Chou, J. -S. (2012). Toward an understanding of construction professionals' acceptance of mobile computing devices in South Korea: An extension of the technology acceptance model. Automation in Construction, 28, 82-90, http://dx.doi.org/10.1016/j.autcon.2012.07.002

Srivastava, J., Wang, J. -H., Lim, E. -P. \& Hwang, S. -Y. (2002). A Case for Analytical Customer Relationship Management. Advances in Knowledge Discovery and Data Mining Lecture Notes in Computer Science, 2336, 14-27, http://dx.doi.org/ 10.1007/3-540-47887-6 3

Stefanou, C. J., Sarmaniotis, C. \& Stafyla, A. (2003). CRM and customer-centric knowledge management: an empirical research. Business Process Management Journal, 9(5), 617-634, http://dx.doi.org/10.1108/14637150310496721

Sternad Zabukovšek, S., Deželak, Z. \& Špička, H. (2007). Model of Critical Success Factors of Implementation SAP and Navision Solutions. Naše gospodarstvo, 1-2, 37-47.

Sternad Zabukovšek, S., Gradišnik, M. \& Bobek, S. (2011). The influence of external factors on routine ERP usage. Industrial Management \& Data Systems, 111(9), 1511-1530, http:// dx.doi.org/10.1108/02635571111182818

Sternad Zabukovšek, S. \& Bobek, S. (2013). TAM-based external factors related to ERP solutions acceptance in organizations. International Journal of Information Systems and Project Management, 1(4), 25-38, http://dx.doi.org/10.12821/ ijispm010402

Šumak, B., Heričko, M. \& Pušnik, M. (2011). A meta-analysis of e-learning technology acceptance: The role of user types and e-learning technology types. Computers in Human Behavior, 27(6), 2067-2077, http://dx.doi.org/10.1016/j. chb.2011.08.005

Tang, J., Pee, L. G. \& Iijima, J. (2013). Investigating the effects of business process orientation on organizational innovation performance. Information \& Management, 50, 650-660, http:// dx.doi.org/ 10.1016/j.im.2013.07.002

Theodosiou, M, Kehagias, J. \& Katsikea, E. (2012). Strategic orientations, marketing capabilities and firm performance: An empirical investigation in the context of frontline managers in service organizations. Industrial Marketing Management, 41, 1058-1070, http://dx.doi.org/10.1016/j. indmarman.2012.01.001

Tufféry, S. (2011). Data Mining and Statistics for Decision Making. West Sussex: John Wiley \& Sons.

Turban, E. \& Volonino, L. (2010). Information technology for management: transforming organizations in the digital economy. New York: John Wiley.

Tuzhilin, A. (2012). Customer relationship management and Web mining: the next frontier. Data Mining and Knowledge Discovery, 24(3), 584-612, doi: 10.1007/s10618-012-0256-Z

Vaman, J. N. (2007). ERP in Practice: ERP Strategies for Steering Organizational Competence and Advantage. New Delhi: McGraw-Hill.
Vijayasarathy, L. R. (2004) Predicting consumer intentions to use on-line shopping: the case for an augmented technology acceptance model. Information \& Management, 41(6), 747-762, http://dx.doi.org/ 10.1016/j.im.2003.08.011

Xie, Y., Xiu, L. \& Weiyun, Y. (2008). A Process Driven Architecture of Analytical CRM Systems with Implementation in Bank Industry. ISECS International Colloquium on Computing, Communication, Control, and Management, 3, 57-61.

Xin, T., Yen, D. C. \& Xiang, F. (2002). Internet integrated customer relationship management: A key success factor for companies in the e-commerce arena. The Journal of Computer Information Systems, 42(3), 77-86.

$\mathrm{Xu}$, M. \& Walton, J. (2005). Gaining customer knowledge through analytical CRM. Industrial Management \& Data Systems, 105(7), 955-971, http://dx.doi.org/10.1108/ 02635570510616139

Zeng, L., Ling, L. \& Duan, L. (2012). Business intelligence in enterprise computing environment. Information Technology and Management, 13(4), 297-310, http://dx.doi.org/10.1007/ s10799-012-0123-z

Zhang, Q. \& Segall, R. S. (2010). Review of data, text and web mining software. Kybernetes, 39(4), 625-655, http://dx.doi. org/10.1108/03684921011036835

Zheng Zhou, K., Gerald Yong Gao, K., Yang, Z. \& Zhou, N. (2005a). Developing strategic orientation in China: antecedents and consequences of market and innovation orientations. Journal of Business Research, 58, 1049-1058, http://dx.doi. org/10.1016/j.jbusres.2004.02.003

Zheng Zhou, K., Yim, C. K. \& Tse, D. K. (2005b). The Effects of Strategic Orientations on Technology- and Market-Based Breakthrough Innovations. Journal of Marketing, 69, 42-60, http://dx.doi.org/10.1509/jmkg.69.2.42.60756

Zheng Zhou, K. \& Li, C. B. (2010). How strategic orientations influence the building of dynamic capability in emerging economies. Journal of Business Research, 63, 224-231, http://dx.doi.org/ 10.1016/j.jbusres.2009.03.003

Zineldin, M. \& Jonsson, P. (2000). An examination of the main factors affecting trust/commitment in supplier-dealer relationships: an empirical study of the Swedish wood industry. The TQM Magazine, 12(4), 245-266, http://dx.doi. org/10.1108/09544780010325831

Žabjek, D., Kovačič, A. \& Indihar Štemberger, M. (2009). The influence of business process management and some other CSFs on successful ERP implementation. Business Process Management Journal, 15(4), 588-608, http://dx.doi. org/10.1108/14637150910975552

Urban Šebjan is a Teaching Assistant in the Department of Quantitative Economic Analysis at the University of Maribor, Faculty of Economics and Business. He has long worked in the Marketing Department of Triglav Insurance Company. He is currently a $\mathrm{PhD}$ student at the University of Maribor - Faculty of Economics and Business, Department of Organization and Informatics. His research focuses primarily on statistical and quantitative methods in economics and business sciences, insurance services, analytical CRM and analytical tools.

Samo Bobek is a Full-time Professor at the University of Maribor, Faculty of Economics and Business (FEB), in 
the Department of E-Business at the. His research areas are IT/IS Governance and Information management, Business solutions, E-business, Banking technology. He has published more than 250 articles, conference papers and book chapters. He teaches information systems and e-business courses on undergraduate, master and doctorate level. $\mathrm{He}$ is also a head of the academic department for E-business where he is a chair of bachelor study programme "E-business « and a chair of master study programme »Information and E-business Management«. $\mathrm{He}$ is a member of the Senate of University. Before being appointed as a dean of FEB in 2007 he was vice dean for research and vice dean for international cooperation at FEB. Professor Bobek also acts as consultant to several corporations, banks and insurance companies in Slovenia.
Polona Tominc is a Full-time Professor in the Department of Quantitative Economic Analysis at the Faculty of Economics and Business, University of Maribor. Her research is focused on statistical methods in economics and business sciences. She teaches statistics and quantitative methods. She participated at more than 30 scientific and professional conferences, is author of chapters in books and articles in scientific and professional journals, published in Slovenia and abroad. She is participating in the DIANA network analysing female entrepreneurship and is a team member of GEM Slovenia and Slovenian entrepreneurship observatory research team. At the moment she is a vice-dean for education at the Faculty of Economics and Business. 